This is the peer reviewed version of the following article: Cho, MyoJung, Ibrahim, Salma and Yan, Yan (2019) The use of nonfinancial performance measures in CEO bonus compensation. Corporate Governance: An International Review, 27(4), pp. 301-316. ISSN (print) 0964-8410, which has been published in final form at https://doi.org/10.1111/corg.12280. This article may be used for non-commercial purposes in accordance with Wiley Terms and Conditions for Use of Self-Archived Versions. 


\section{The Use of Nonfinancial Performance Measures in CEO Bonus Compensation}

\section{Manuscript Type: Empirical}

Research Question/Issue: In this study, we explore the relationship between the use of nonfinancial performance measures in Chief Executive Officer (CEO) bonus plans and CEO power, moderated by compensation committee monitoring. Furthermore, we investigate whether the inclusion of nonfinancial performance measures is associated with higher CEO bonus pay sensitivity to shareholder returns.

Research Findings/Insights: Using a sample of FTSE 350 firms during the period 2007-2013, we find that CEO power is significantly negatively related to the propensity of using nonfinancial performance measures. This negative relationship, however, is moderated by higher levels of compensation committee monitoring. We also find that firms combining nonfinancial and financial performance measures in CEO bonus plans tend to have stronger CEO bonus pay sensitivity to shareholder returns than firms using financial measures alone. Thus, our results suggest that boards of directors adopting nonfinancial performance measures are able to better align CEO incentives with shareholder interests. We find similar results when using the weight of nonfinancial performance measures in the bonus plan in our analyses.

Theoretical/Academic Implications: This study empirically supports the managerial power theory whereby powerful CEOs influence the choice of performance measures in their bonus plans. However, effective compensation committees are found to attenuate the influence of powerful CEOs and to better align their interests with those of shareholders. Our result of stronger bonus pay sensitivity to shareholder returns for firms combining nonfinancial with financial performance measures implies that the informativeness of these measures enhances the firm's ability to tie CEO bonus compensation to shareholder wealth.

Practitioner/Policy Implications: This study offers insights to members of boards of directors, especially compensation committee members, who are interested in improving the design of executive incentive contracts to better align managerial incentives to shareholder interests. Furthermore, the findings inform regulators about the importance of alternative performance measures in pay-performance sensitivity and may warrant increased firm disclosure of the details of the pay structure.

Key words: Corporate Governance; CEO Power; Compensation Committee Monitoring; CEO Bonus Compensation; Nonfinancial Performance Measures; Pay-performance Sensitivity. 


\section{INTRODUCTION}

In this study, we explore the relationship between the use of nonfinancial performance measures in Chief Executive Officer (CEO) bonus compensation and CEO power, and the moderating role of the compensation committee monitoring on this relationship. Furthermore, we investigate whether the inclusion of nonfinancial performance measures in CEO bonus plans, alongside financial measures, is associated with higher CEO bonus pay sensitivity to shareholder returns. Prior literature finds that nonfinancial performance measures are informative about unobservable managerial actions and allow a more balanced assessment of the CEO's performance (Ittner, Larcker and Rajan, 1997; Epstein and Roy, 2004; Schiehll and Bellavance, 2009). Therefore, we hypothesize that firms whose CEOs have greater power over the boards are less likely to use nonfinancial performance measures in CEO bonus plans.

To test our hypothesis, we use a sample of FTSE firms in the United Kingdom (UK) during the period 2007-2013. We focus on a UK sample because a series of corporate governance reforms in the past decades has encouraged companies to implement performance-related compensation in the UK (Cadbury, 1992; Greenbury, 1995; UK Government, 2013), as well as requiring the formation of compensation committees consisting of independent directors (e.g. UK Corporate Governance Code, 2010). We find that CEO power is significantly negatively related to the propensity of using nonfinancial performance measures in CEO bonus contracts. This is in line with the finding in Schiehll and Bellavance (2009) that the use of nonfinancial measures in incentive contracts may be a substitute for CEO ownership, a proxy for CEO power.

CEO power is a relative concept based on the relationship between the CEO and other board members (Schiehll, Lewellyn and Muller-Kahle, 2018). Therefore, we examine the moderating role of the compensation committee in the choice of nonfinancial performance measures. We find that effective compensation committee monitoring attenuates the influence 
of CEO power over board decisions. Specifically, the negative relationship between CEO power and the use of nonfinancial performance measures is less pronounced when the compensation committee monitoring function is more effective. We also investigate whether the use of nonfinancial performance measures, which are informative of CEO actions, in bonus compensation can strengthen CEO bonus pay-performance sensitivity. We expect and find that integrating nonfinancial performance measures in CEO bonus plans will help align CEO and shareholder interests. This effect is more pronounced when compensation committees are more independent. In addition, we find that CEO bonus pay sensitivity to shareholder returns becomes stronger as the contractual weight of nonfinancial performance measures increases.

Our study contributes to the literature in the following ways. First, we investigate the relative dynamics of CEO power and compensation committee monitoring in the choice of performance measures in CEO bonus plans. Our study extends prior work, such as Schiehll and Bellavance (2009), which tends to examine the stand-alone effect of CEO power and board monitoring on the choice of integrating nonfinancial performance measures in CEO bonus plans. Second, our measure of CEO power covers all four dimensions of power discussed by Finkelstein (1992). This contribution highlights the significance of our findings because prior studies tend to infer CEO power from one or two variables (e.g. duality and number of board members appointed following the CEO's appointment in Ittner, Larcker, and Rajan, 1997; CEO ownership in Schiehll and Bellavance, 2009). Third, we shed light on the monitoring role of compensation committees in an alternative setting of performance evaluation measure choices. Prior literature tends to investigate the committee's role in decisions of executive compensation levels (Daily, Johnson, Ellstrand and Dalton, 1998) or pay structure (Anderson and Bizjak, 2003), rather than the choice of performance measures. Lastly and most importantly, our study is the first to report the positive impact of nonfinancial 
performance measures on the link between CEO bonus compensation and shareholder returns.

Our results have important implications for boards of directors and policy makers, who are interested in aligning CEO and shareholder interests. Specifically, boards of directors and compensation committees may consider adopting nonfinancial performance measures in executive incentive contracts. Regulators may contemplate providing further recommendations on the choice of performance measures in CEO compensation contracts. Current regulations do not discuss this choice (UK Corporate Governance Code, 2018). Furthermore, regulators may improve pay-performance sensitivity if they require enhanced disclosure of CEO pay structure with detailed description of alternative performance measures in bonus plans.

The remainder of the paper is organized as follows. We review the institutional environment of the UK and related literature in the next section. This is followed by the hypotheses development. The sample, estimation methods, regression models, and variables are then documented, followed by a discussion of the results. We present the conclusion, implications, and limitations in the last section.

\section{INSTITUTIONAL ENVIRONMENT IN THE UNITED KINGDOM}

The UK renders a unique setting for examining the choice of performance measures in executive compensation due to the extensive regulation on governance and performance-related pay. Specifically, the Cadbury report (Cadbury, 1992) recommended firms to set up compensation committees mainly consisting of non-executive directors. The Greenbury report (Greenbury, 1995) and the Hampel report (Hampel, 1998) further highlighted the importance of linking rewards to performance. In 1998, the Combined Code (renamed in 2010 as the Corporate Governance Code) integrated the recommendations from 
the Cadbury, Greenbury and Hampel reports. The importance of performance measures in executive compensation has been highlighted in several revisions of the UK Corporate Governance Code. The 2016 version of the Code states that: 'Executive directors' remuneration should be designed to promote the long-term success of the company. Performance-related elements should be transparent, stretching and rigorously applied' (Section D: Remuneration). However, in the latest version of 2018, reference to performance measures is minimal and the Code only requires compensation committees to provide the rationale for remuneration policies including any 'performance metrics' (Section 5; Provision 41).

Extant empirical research on the choice of performance measures in executive compensation is usually conducted using US data. However, there are some significant differences in the governance structure between the UK and US, including: the type of institutional investors (insurance companies and hedge funds in the UK; investment companies in the UK), the duality of the $\mathrm{CEO} /$ chairman role (rare in the $\mathrm{UK}$; prominent in the US) and the engagement or monitoring of institutional investors (encouraged in the UK) (Aguilera, Williams, Conley and Rupp, 2006). Our study adds the understanding of the role of performance measures used in CEO bonus compensation in the unique UK setting.

\section{HYPOTHESES DEVELOPMENT}

\section{CEO Power, Monitoring and the Choice of Performance Measures}

Under agency theory, the goal of the board of directors is to incentivize and monitor CEOs to closely align their interests with shareholder interests (Jensen and Meckling, 1976; Lo and $\mathrm{Wu}, 2016)$. The choice of performance measures in CEO bonus plans is, therefore, an important consideration as a tool for incentivizing CEOs (Schiehll and Bellavance, 2009). Boards of directors are expected to incorporate performance measures in bonus contracts if 
they are informative, providing incremental information about managerial actions (Holmstrom, 1979; Banker and Datar, 1989; Feltham and Xie, 1994). Firms usually rely on financial performance measures such as accounting earnings or stock returns in bonus contracts (Holmstrom and Milgrom, 1991; Bushman, Indjejikian and Smith, 1996). Prior studies suggest that nonfinancial performance measures provide incremental information about managerial actions that are not observable in financial measures (Kaplan and Norton, 1992; Hemmer, 1996; Ittner, Larcker and Rajan, 1997; Said, HassabElnaby and Wier, 2003; Davila and Venkatachalam, 2004; Epstein and Roy, 2004). Therefore, we expect that boards of directors are inclined to adopt nonfinancial performance measures for their incremental information, conditional on factors like monitoring costs, resources or competition.

Studies of managerial power theory contend that CEOs with high managerial power may influence board decisions on compensation so that the resulting compensation contracts are favorable for themselves (Hill and Phan, 1995; Bebchuk and Fried, 2004; Bender and Moir, 2006; Florackis and Ozkan, 2009; van Essen, Otten, and Carberry, 2015). Prior research has also established the influence of CEOs in the governance structure in different contexts. For example, CEO power may limit the board's influence over corporate strategies (Haynes and Hillman, 2010; Chin, Hambrick and Trevino, 2013; Zhu and Chen, 2015). A CEO who also serves as the chairman of the board of directors can decide the board meeting agenda and lead board meeting discussions (Finkelstein, 1992; Daily and Johnson, 1997; Ittner, Larcker and Rajan, 1997; Krause, Semadeni and Cannella, 2014). Furthermore, powerful CEOs have greater influence on the selection process of directors and are better positioned to limit board influence on important firm decisions (Finkelstein, 1992; Davila and Venkatachalam, 2004; Haynes and Hillman, 2010; Veprauskaite and Adams, 2013).

If CEOs with greater power interfere with decisions of boards of directors on the choice of performance measures to favor themselves, we expect that they are less likely to 
adopt nonfinancial performance measures even if those measures may be future-oriented and informative of unobservable managerial actions. Thus, we hypothesize a negative relationship between the propensity of using nonfinancial performance measures and CEO power as follows:

$\boldsymbol{H}_{1 a}:$ Firms with greater $C E O$ power are less likely to use nonfinancial performance measures in CEO bonus compensation.

Power is defined as 'the capacity of individual actors to exert their will' and to achieve their goals in a particular relationship (Pfeffer, 1981; Hambrick and Fukutomi, 1991; Finkelstein, 1992; Schiehll, Lewellyn and Muller-Kahle, 2018). However, power is a relative concept and depends on other organizational actors (Pfeffer, 1981; Hambrick and Fukutomi, 1991; Shen and Cannella, 2002; Schiehll, Lewellyn and Muller-Kahle, 2018). Both agency theory and managerial power theory suggest that effective board monitoring attenuates the influence of powerful CEOs on incentive contracts (Jensen and Meckling, 1976; Daily and Johnson, 1997; Bebchuk and Fried, 2004; van Essen, Otten and Carberry, 2015). Prior studies find that boards with more effective monitoring, reflected through more independent boards, are, on average, in a better position to force CEOs to act in the shareholders' interests (Beatty \& Zajac, 1994; Conyon and Peck, 1998). Jensen and Meckling (1976) theoretically show that monitoring increases shareholder wealth but increases CEO's wealth to a less extent by limiting non-pecuniary benefits, which the CEO could have enjoyed without monitoring. Therefore, we expect that effective board monitoring moderates the influence of a powerful CEO on incentive contract decisions of the board. Specifically, firms with powerful CEOs, if they are closely monitored by the boards of directors, would be relatively more inclined to include informative nonfinancial performance measures in bonus contracts than firms with powerful CEOs and weak board monitoring. To estimate the effect of board monitoring, we focus on the monitoring role of compensation committee since our study focuses on executive 
compensation (Newman and Mozes, 1999; Anderson and Bizjak, 2003; Bebchuk and Fried, 2004; Conyon and He, 2004; Laux and Laux, 2009; Sun and Cahan, 2009). This leads to the following hypothesis:

$\boldsymbol{H}_{1 b}$ : The negative association between CEO power and the use of nonfinancial performance measures in CEO bonus compensation becomes weaker for firms with better compensation committee monitoring.

\section{Pay-performance Sensitivity and Nonfinancial Performance Measures}

Board decisions of performance measures have a direct impact on CEO compensation and its relation to shareholder returns. Extant research on executive compensation in the context of the UK has found a positive but weak relationship between the level of compensation and shareholder value (Gregg, Machin and Szymanski, 1993; Conyon, 1997; Ozkan, 2011). Prior studies suggest that the inclusion of nonfinancial performance measures in incentive contracts could promote the board's assessment of managerial actions that are not publicly observable and in turn, enable the boards to better monitor the managers (Banker and Datar, 1989; Kaplan and Norton, 1992; Sliwka, 2002; Banker, Potter and Srinivasan, 2005; Schiehll and Bellavance, 2009). Therefore, we investigate whether combining nonfinancial with financial performance measures improves the relationship between CEO bonus compensation and shareholder wealth, irrespective of the influence of managerial power over board decisions.

Prior studies report that nonfinancial and financial measures complement each other in reducing agency costs (Baker, Gibbons and Murphy, 1994; Ghosh and $\mathrm{Wu}, 2012$ ). Nonfinancial measures are more forward-looking than financial measures (Ittner and Larcker 1998; Banker, Potter, and Srinivasan, 2000; Said, HassabElnaby and Wier, 2003). Nonfinancial measures also discourage earnings manipulation (HassabElnaby, Mohamed and 
Said, 2010; Ibrahim and Lloyd, 2011). They provide for better managerial incentives, especially for firms with high growth rates or firms with noisy financial measures (Bushman, Indjejikian and Smith, 1996). Therefore, we expect that, if nonfinancial performance measures are included in bonus contracts, the positive relationship between CEO bonus compensation and shareholder returns (pay-performance sensitivity) will be stronger in the following hypothesis:

$\boldsymbol{H}_{2}:$ The sensitivity of CEO bonus compensation to shareholder returns is higher in firms that combine nonfinancial and financial performance measures than firms that rely on financial performance measures alone.

\section{DATA AND RESEARCH METHODOLOGY}

\section{Data and Sample}

For our sample, we use firms listed on the FTSE 350 index in the years 2007-2013. We focus on FTSE 350 firms following prior research on pay-performance sensitivity in the UK (Buck, Bruce, Main and Udueni, 2003). Our starting year is 2007 since most governance variables specific to the compensation committee are available from 2007. We manually collect information about CEO bonus compensation and the type of performance measures from the annual reports. We also collect the contractual weight placed on nonfinancial performance measures, if disclosed. Nonfinancial measures are those that cannot be defined in financial terms and include measures such as customer satisfaction, employee satisfaction, safety and environment, and other qualitative factors. Examples of other qualitative factors include personal objectives set for the CEO (e.g. 2012 annual report of Cairn, PLC) and initiatives such as increasing efficiencies and focusing on e-commerce (2012 annual report of Morrisons, PLC). ${ }^{1}$ Data on stock returns and firm characteristics are collected from Datastream. 
We exclude observations from the financial sector as this sector has a special regulatory environment. We delete observations with no clear information of performance measures used in bonus plans or firms without CEO incentive plans. We further remove observations with partial-year CEO compensation to exclude any effects of changes in compensation contracts if new CEOs are appointed. Lastly, we exclude observations with any missing test variables specified in our regression models. We winsorize extreme values of our continuous independent variables, stock returns and return on equity, at one percent to avoid the influence of outliers.

We obtain variables of CEO share ownership, board of directors' share ownership, CEO tenure and age, compensation committee size and independence as well as compensation committee chair independence, from the governance database, NRG Metrics. ${ }^{2}$ These are used to measure CEO power and monitoring proxies. Our final sample consists of 1,097 firm-year observations of 204 firms with non-missing variables during the period 2007-2013. Out of these, 693 observations (63 percent) are for firms combining nonfinancial and financial performance measures in bonus compensation contracts.

\section{CEO Power Index}

To measure our proxy of CEO power, we develop a composite index, CEO Power, based on the four dimensions of power discussed by Finkelstein (1992) - structural power, ownership power, expert power and prestige power. We proxy for structural power with Duality, which takes the value of one if the CEO is also the chairman of the board, and zero otherwise (Finkelstein and D'aveni, 1994; Ittner, Larcker and Rajan, 1997; Hu and Kumar, 2004). We proxy for ownership power with Relative CEO Ownership Index, which takes the value of one if the ratio of shares held by the CEO to those held by other board members is greater than the median of our sample distribution, and zero otherwise. As an indicator of expertise power, we use CEO Tenure Index (Hambrick and Fukutomi, 1991; Hill and Phan, 
1991). CEO Tenure Index is coded as one if the number of years serving as a CEO is greater than the median of our sample distribution, and zero otherwise. We proxy for prestige power with CEO Age Index (Coughlan and Schmidt, 1985), which takes the value of one if the CEO's age is above the median sample distribution, and zero otherwise.

Our index, CEO Power, is the sum of Duality, Relative CEO Ownership Index, CEO Tenure Index, and CEO Age Index, taking on values ranging from 0 to 4 . A higher $C E O$ Power indicates greater managerial power. Prior managerial power studies have used similar methodologies of combining multiple governance variables into an index variable (e.g. Han, Nanda and Silveri, 2016; Mathew, Ibrahim and Archbold, 2018).

\section{Monitoring Index}

While prior research tends to focus on the role of the board of directors in monitoring (Beatty and Zajac, 1994; Core, Holthausen and Larcker, 1999; Combs et al., 2007; Schiehll, 2008), we focus on the compensation committee in the setting of bonus compensation. To proxy for compensation committee monitoring, we identify several factors that may restrict CEO power or affect the quality of compensation committees, including compensation committee independence (e.g. Conyon and Peck, 1998), committee chair independence, and compensation committee size (Bushman, Chen, Engel and Smith, 2004; Song and Windram, 2004; Sun and Cahan, 2009).

Our first measure, Compensation Committee Independence Index takes the value one if the number of independent members of the committee of a firm is more than the median number of our sample distribution, and zero otherwise. Compensation Committee Chair Independence takes the value of one if the chair is an independent member of the board of directors, and zero otherwise. Compensation Committee Size Index is coded as one if the number of committee members of a firm is greater than the median number of our sample 
distribution, and zero otherwise. ${ }^{3}$ Our compensation committee monitoring variable, Monitoring, is the sum of Compensation Committee Independence Index, Committee Chair Independence, and Compensation Committee Size Index, ranging from 0 to 3.

\section{Research Methodology}

Hypotheses $1 \mathrm{a}$ and $1 \mathrm{~b}$ investigate the relationship between CEO power and the propensity of using nonfinancial performance measures in CEO bonus plans, moderated by the effect of compensation committee monitoring. We use the following multivariate logistic regression model with robust standard errors: ${ }^{4}$

Nonfinancial $_{i t}=\beta_{1}$ CEO Power $_{i t-1}+\beta_{2}$ CEO Power $_{i t}$ Monitoring $_{i t-1}+\beta_{3}$ Monitoring $_{i t-1}+$

$$
\sum \beta_{k} \text { Controls }_{k i t-1}+\alpha+\varepsilon_{i t}
$$

Nonfinancial is an indicator variable equal to one if a firm uses nonfinancial performance measures in the CEO bonus plan, and zero otherwise, for firm $i$ in year $t$ (Said, HassabElnaby and Wier, 2003; Schiehll and Bellavance, 2009). We also use an alternative measure, Nonfinancial Weight, which is the actual weight placed on nonfinancial measures in the bonus contract (zero for firms that use financial measures alone or actual weight of nonfinancial measures if provided). This weight measure is similar to that used in Ittner, Larcker and Rajan $(1997){ }^{5}$

Our independent test variables include CEO Power and Monitoring as well as the interaction term of CEO Power $\cdot$ Monitoring capturing the moderating effect of compensation committee monitoring. Hypothesis 1a expects a negative coefficient, $\beta_{1}$ and Hypothesis $1 \mathrm{~b}$ expects a positive coefficient, $\beta_{2}$. We have no expectation about the stand-alone effect of Monitoring. Given that bonuses are paid (and their associated performance measures are disclosed) one year after the selection of performance measures by compensation committees (e.g. McKnight and Tomkins, 1999), lagged values of the independent variables are used in 
the model.

We include several control variables. Firm Size is used to control for firm complexity and agency conflicts (Ryan and Wiggins, 2001). It is measured as the log transformation of total assets at the end of year $t$ (Garen, 1994). Firm Age is the number of years since the founding year (Cordeiro, He, Conyon and Shaw, 2013). Leverage proxies for firm's risk and represents a firm's capital structure; this is measured as total debts divided by total assets (Firth, Leung and Rui, 2010). Market-to-Book ratio controls for the firms' growth opportunity, which is calculated as market capitalization divided by total shareholders' equity (Firth, Fung and Rui, 2007). Financial Crisis is included to control for macroeconomic shocks, and it is equal to one if the observation is from the period 2007-2008, and zero otherwise (Fahlenbrach and Stulz, 2011). We include the Herfindahl Index, calculated as the sum of squared market share of the firm (percentage share of sales revenues within its industry) to control for competition (Chen, Matsumura, Shin and Wu, 2015). ${ }^{6}$ Finally, Year and Industry are indicator variables of firm-year and industry membership. They are included to cater for year effects and to allow for cross-industry variation, respectively.

Hypothesis 2 investigates whether the inclusion of nonfinancial performance measures in bonus contracts enhances CEO bonus compensation sensitivity to shareholder returns. To test this hypothesis, we use the following model including an interaction term between Nonfinancial and annual stock returns (RET). We also include return on equity $(R O E)$ as an alternative performance measure, and its interaction with the Nonfinancial variable as follows:

$\log \left(\right.$ Bonus $\left._{i t}\right)=\beta_{1}$ RET $_{i t}+\beta_{2}$ Nonfinancial $_{i t} \cdot$ RET $_{i t}+\beta_{3}$ ROE $_{i t}+\beta_{4}$ Nonfinancial $_{i t} \cdot$ ROE $_{i t}+$ $\beta_{5}$ Nonfinancial $_{i t}+\sum \beta_{k}$ Controls $_{k i t}+\alpha+\varepsilon_{i t}$

$\log ($ Bonus $)$ is the $\log$ transformation of CEO bonus of firm $i$ in year $t$. We use the $\log$ 
transformation of the bonus level to mitigate the problem of skewed distributions (Andreas, Rapp and Wolff, 2012; Conyon and He, 2012). RET is annual stock returns, excluding dividends, as in Conyon and $\mathrm{He}$ (2011). ROE is return on equity, which is net income divided by total shareholders' equity. We use both $R E T$ and $R O E$ in the regression to capture both market and accounting performance (Leone, Wu and Zimmerman, 2006; Shaw and Zhang, 2010). ${ }^{7}$ We control for Board Size and Board Independence in addition to the control variables in Equation (1) because governance mechanisms can reduce conflicts of interests between the CEO and shareholders and affect the pay-performance sensitivity (Ozkan, 2011).

We use the fixed-effect panel data estimation for Equation (2), as in Schaefer (1998), since pay and other firm-related characteristics may not vary across time. Standard errors are clustered by firms, and year dummies control for cross-sectional and time-series dependence (Petersen, 2009).

We focus on CEO bonus compensation not on long-term or total compensation in our analyses for two reasons. First, firms in the UK were not formally required to disclose a single total compensation figure for executives until the "2013 reforms" (UK Government, 2013). Prior to 2013, many firms chose to report cash-related compensation rather than a single total figure and data on long-term incentive pay were not always quantified in the reports. Second, long-term pay is usually tied to financial performance measures only (Ibrahim and Lloyd, 2011).

\section{RESULTS AND DISCUSSION}

\section{Descriptive Statistics}

We begin by presenting the distribution of our sample across the sample period and across industries designated by FTSE. The sample distribution is shown separately for observations of firms that use financial and nonfinancial performance measures and those that 
use financial measures alone in their CEO bonus plans. Panel A of Table 1 shows that nonfinancial performance measures have become more popular over the sample period (from 59 percent of the observations in 2007 to 66 percent in 2013). The number of firms relying on financial performance measures alone has declined over time, from a high of 66 firms in 2008 to a low of 45 in 2013. Panel B of Table 1 shows that the highest number of observations belongs to the industrials industry (financial measures alone, $\mathrm{N}=171$; both financial and nonfinancial measures, $\mathrm{N}=196$ ). The second largest industry is the consumer services industry (financial measures alone, $\mathrm{N}=89$; both financial and nonfinancial measures, $\mathrm{N}=$ 189). More than 80 percent of the observations in the health care (91.11 percent), oil and gas (82.35 percent), and telecommunications (82.05 percent) industries adopt both financial and nonfinancial performance measures in our sample.

\section{$<$ Insert Table 1 about here $>$}

Panel A of Table 2 reports descriptive statistics for the full sample. The average bonus of CEOs in our sample is $£ 567,400$. On average, 63 percent of the sample observations combine nonfinancial and financial performance measures in CEO bonus plans with Nonfinancial $=1$, which represents 693 observations. Out of these 693 observations, 426 have disclosed information on the values of Nonfinancial Weight and the average Nonfinancial Weight is 26 percent. Mean stock returns $R E T$ and return on equity $R O E$ are both 17 percent. The number of years for which the CEOs in our sample have been in office is on average 6.7 years and their average age is 52 years. Only 2 percent of CEOs in our sample combine both roles of CEO and Chairman of the board (mean Duality $=2$ percent). In terms of compensation committee variables, we find that the committees tend to be fully independent (mean Compensation Committee Independence $=0.90$ ) with an independent chair (mean Compensation Committee Chair Independence $=0.96$ ). Firms in the sample are well established with mean Firm Age of 67 years and mean Leverage of 30 percent. 
Panel B provides descriptive statistics of the test variables in firms that use financial performance measures alone compared to those that combine nonfinancial with financial performance measures. The stock returns for firms using nonfinancial performance measures as well (mean $R E T=16$ percent) are statistically indifferent from those using financial measures alone (mean $R E T=17$ percent). The two groups differ in terms of CEO Power and Monitoring. Specifically, the mean CEO Power is 1.69 in firms using financial measures alone but 1.52 in firms using both financial and nonfinancial measures. The difference is statistically significant at the 1 percent level. The mean Monitoring is 2.2 in firms using financial measures alone compared to 2.3 in firms using financial and nonfinancial measures (significantly different at the 5 percent level).

$<$ Insert Table 2 about here $>$

Table 3 presents the Pearson correlation coefficients between our key variables. $\log$ (Bonus) is positively correlated with Nonfinancial with a correlation coefficient of 0.07 , significant at the 5 percent level. However, $\log$ (Bonus) is not significantly related to $C E O$ Power or Monitoring. Nonfinancial is significantly related to several variables including: ROE (coefficient -0.10 , significant at the 1 percent level), CEO Power (coefficient -0.08 , significant at the 1 percent level) and Monitoring (coefficient 0.06 , significant at the 5 percent level Board Size and Firm Size are highly correlated with the coefficient of 0.57, significant at the 1 percent level. Overall, it is unlikely that our regressions have multicollinearity issues.

$<$ Insert Table 3 about here $>$

\section{Results of Hypotheses 1a and 1b: CEO Power, Monitoring and Nonfinancial Measures}

Table 4 presents the results of Hypotheses 1a and 1b using Equation (1), investigating the association between CEO power and the propensity of using nonfinancial performance measures in CEO bonus plans, as well as the moderating effect of monitoring. In column 1, 
we find that $C E O$ Power has a negative coefficient of -1.09 , significant at the 1 percent level. This result supports Hypothesis 1a and suggests that firms are less likely to include nonfinancial measures in CEO bonus compensation plans when the CEO has more managerial power. The coefficient of CEO Power-Monitoring is positive and significant (coefficient is 0.38 , significant at the 1 percent level), supporting Hypothesis $1 \mathrm{~b}$. That is, the influence of CEO power on board decisions is attenuated by stronger boards through an effective compensation committee monitoring. The first column of Table 4 also shows that the coefficient on Monitoring is insignificant and large firms are more likely to adopt nonfinancial measures (coefficient of Firm Size is 0.47 , significant at the 1 percent level). We also find a negative coefficient of Leverage, indicating that more leveraged firms are less likely to use nonfinancial performance measures, consistent with prior studies (Opler and Titman, 1994; Ittner, Larcker and Rajan, 1997; Said, HassabElnaby and Wier, 2003). However, the coefficient is not significant at conventional levels.

\section{$<$ Insert Table 4 about here $>$}

The second column of Table 4 reports the results with the alternative dependent variable, Nonfinancial Weight. Similar to the results with Nonfinancial, we find a negative association between CEO Power and Nonfinancial Weight (coefficient is -0.04 , significant at the 5 percent level). The interaction term of CEO Power with Monitoring is positive and significant (coefficient is 0.01 , significant at the 10 percent level). This result is similar to findings in Ittner, Larcker, and Rajan (1997), whereby they report that CEOs with greater influence over the board of directors are less likely to be compensated based on nonfinancial measures. ${ }^{8}$ The second column of Table 4 also reports that larger firms tend to place more weight on nonfinancial performance measures (coefficient of Firm Size is 0.03 , significant at the 1 percent level). Furthermore, Leverage is negatively related to Nonfinancial Weight (significant at the 10 percent level). 
To visualize the effect of CEO Power and Monitoring on the choice of nonfinancial performance measures we present, in Figure 1, a plot of the association between CEO Power and the use of nonfinancial performance measures, at different levels of Monitoring. The plot indicates a negative relationship between $C E O$ Power and the use of nonfinancial measures (Nonfinancial), with a negative slope. However, the negative relationship is less pronounced at higher levels of committee monitoring. Specifically, the negative slope is steeper when the level of compensation committee monitoring is low (Monitoring $=0$ or 1 ; represented by solid line), compared to when Monitoring is high (Monitoring $=2$ or 3; represented by dashed line). This is in line with the results in Table 4 showing the moderating effect of Monitoring on the negative relationship between CEO power and the propensity of use of nonfinancial performance measures (Nonfinancial).

$<$ Insert Figure 1 about here $>$

Overall, our results are consistent with the notion that while firms with powerful CEOs are less likely to adopt nonfinancial performance measures, the influence of powerful CEOs is tempered by effective compensation committee monitoring. Our results are consistent with Schiehll and Bellavance (2009), which report that more independent boards integrate more nonfinancial performance measures in $\mathrm{CEO}$ bonus plans because insider-dominated boards may not want to include these costly nonfinancial measures.

\section{Results of Hypothesis 2: Bonus Pay Sensitivity to Shareholder Returns and Nonfinancial Performance Measures}

Hypothesis 2 investigates whether firms with nonfinancial performance measures have stronger bonus pay-sensitivity to shareholder returns. The first column of Table 5 presents regression results of Equation (2). The coefficient of the interaction term, Nonfinancial-RET, is 1.13 , significantly positive at the 5 percent level. This result suggests that firms combining 
nonfinancial and financial performance measures enhance CEO bonus pay sensitivity to shareholder returns, supporting Hypothesis 2. We also find a significant and positive coefficient on Nonfinancial-ROE, which suggests the higher sensitivity of bonus pay to accounting performance for those firms combining nonfinancial and financial measures (coefficient is 0.73 , significant at the 10 percent level). We find higher bonus pay in larger firms (coefficient on Firm Size is 0.41 , significant at the 1 percent level), with higher board independence (coefficient is 2.70 , significant at the 1 percent level) and during the financial crisis (coefficient on Financial Crisis is 0.63 , significant at the 5 percent level). We also find lower bonus pay in more competitive industries (coefficient on Herfindahl Index is-5.15, significant at the 1 percent level).

The overall explanatory power of our model is 7 percent, which is similar to extant pay sensitivity models with cash compensation based on UK data. For example, Ozkan (2011) reports an $\mathrm{R}^{2}$ of 2 percent from their model of change in log cash pay on log of shareholder returns (Table 3, p. 275). Unlike our study, prior research with higher explanatory power tends to use long-term pay based or US data. For example, Conyon and Murphy (2000) report an $\mathrm{R}^{2}$ of 31 percent in pay-performance regressions using US and UK data (Table 4, p. F654). Buck, Bruce, Main and Udueni (2003) report an $\mathrm{R}^{2}$ of 33 percent in pay-performance regressions using cash and long-term pay (Table II, p. 1721).

\section{$<$ Insert Table 5 about here $>$}

The second column in Table 5 presents the results using Nonfinancial Weight as an alternative to Nonfinancial in Equation (2). We find pay-performance sensitivity to be higher when the weight placed on nonfinancial performance measures is higher (coefficient of Nonfinancial Weight $\cdot R E T$ is 2.72 ), although this is not statistically significant at conventional levels. We also find that Board Independence and Firm Size are positively related to $\log$ (Bonus), while Herfindahl Index is negatively related to $\log$ (Bonus). 
We present in Figure 2 a plot of the pay-performance sensitivity for firms that employ financial performance measures alone $($ Nonfinancial $=0)$ and those that combine nonfinancial with financial performance measures (Nonfinancial $=1$ ), using $R E T$ as a proxy for shareholder wealth. The plot shows a positive relationship between CEO bonus and shareholder returns and the positive relationship is stronger for firms combining nonfinancial and financial performance measures (dashed line with Nonfinancial $=1$ ) than firms using financial measures alone. This is in line with the optimal contracting theory, implying that once firms adopt nonfinancial performance measures, the informative nature of nonfinancial measures facilitates a stronger tie between CEO bonus pay and stock returns.

$<$ Insert Figure 2 about here $>$

\section{Bonus Pay Sensitivity to Shareholder Returns and Nonfinancial Performance Measures - Effect of Monitoring}

In the tests of Hypotheses $1 \mathrm{a}$ and $1 \mathrm{~b}$, we report that firms with higher CEO power are less likely to use nonfinancial performance measures and this result is attenuated by more effective board monitoring. In this section, we further investigate the impact of board monitoring on the pay-performance sensitivity to shareholder returns. We estimate Equation (2) after dividing our sample into two groups based on the level of board monitoring: a group with high compensation committee independence (all members of committee are independent; $\mathrm{N}=702$ ) and a group with low committee independence (at least one member is not independent; $\mathrm{N}=395$ ).

The results are presented in Table 6 . The results show that the coefficient on Nonfinancial-RET is significant for firms with high committee independence (1.39, significant at the 5 percent level), but not for firms with low committee independence (coefficient of Nonfinancial-RET is 0.45 and insignificant). Our results suggest that when 
nonfinancial performance measures are integrated in incentive contracts, they help align interests of CEOs and shareholders, and this result is stronger for firms with more effective compensation committee monitoring. ${ }^{9}$

$<$ Insert Table 6 about here $>$

\section{Robustness Tests}

Alternative measures of CEO Power

As robustness tests of Hypothesis 1, we use three alternative measures of CEO Power. The first alternative is an index measure based on Duality, CEO Tenure Index and CEO Age Index in addition to an alternative CEO ownership variable, CEO Ownership Index, which is set as one if the actual percentage of shares held by the CEO is above 3 percent, zero otherwise. This index is similar to the index in Veprauskaite and Adams (2013). We add Duality, CEO Tenure Index, CEO Age Index and CEO Ownership Index and the resulting index ranges from 0 to 4 . The second alternative index for CEO power is measured by adding Duality and Relative CEO Ownership Index, excluding CEO Tenure Index and CEO Age Index. The resulting index takes values from 0 to 2 . We exclude the latter two variables given that more appropriate variables for tenure and age are those of the CEO relative to tenure and age of other board members. However, we do not have data on other board member characteristics. As the third alternative, we use CEO Tenure alone as a proxy of CEO power (e.g. Hill and Phan, 1991), which ranges from 1 to 42 . All results (untabulated) remain qualitatively the same across the three alternatives of $C E O$ Power.

\section{Control for selection bias}

Our results show the importance of CEO power and board monitoring in the choice of performance evaluation measures. We contemplate that it is possible that firms adopt nonfinancial measures because they are more likely to have superior performance results of 
nonfinancial measures. Thus, we control for the potential selection bias associated with CEO power and other omitted variables in our tests for Hypothesis 2. To address the problem, we rerun our tests using a two-stage regression methodology, which is similar to the two-stage least squares (2SLS) instrumental variable estimator method. In the first stage model (untabulated), we regress the propensity of adopting nonfinancial performance measure (Nonfinancial) on CEO Power, Monitoring and other lagged control variables presented in Table 4 (excluding the interaction term CEO Power 'Monitoring, RET and ROE). Lagged Firm Size and lagged Leverage control for the political pressure or regulatory environment and the financial condition of the firm (Ittner, Larcker and Rajan, 1997; Said, HassabElnaby and Wier, 2003). In addition, we separately estimate the first stage model with Nonfinancial Weight as a dependent variable. Given that Nonfinancial Weight is a continuous variable, we use ordinary least square regressions with clustered standard errors.

In the second stage estimation, we use the predicted propensity of using nonfinancial measures (as well as predicted Nonfinancial Weight) estimated from the first stage model and replace Nonfinancial or Nonfinancial Weight with their predicted values in Equation (2). Table 7 shows that the results are similar to our main results in Table 5. Specifically, firms using nonfinancial performance measures enjoy a significant improvement of bonus pay-sensitivity to shareholder returns with a significantly positive coefficient of 5.78 for the interaction term Nonfinancial-RET at the 1 percent level. The coefficient of Nonfinancial Weight $\cdot R E T$ is also positive and significant (19.84, significant at the 1 percent level).

$$
<\text { Insert Table } 7 \text { about here }>
$$

\section{Control for effect of interaction terms}

When including interaction terms in regressions, the coefficients of the main effect may suffer multicollinearity problems. Therefore, we follow Bellavance, Landry and Schiehll 
(2013) and center $R E T$ and $R O E$, by subtracting the sample mean of each variable from each observation's value of RET and ROE. Using the centered values of $R E T$ and $R O E$, we rerun Equation (2). The results (untabulated) indicate that the coefficient of Nonfinancial is insignificant and the coefficients of $R E T$ and $R O E$ as well as their interaction terms with Nonfinancial remain unchanged to those reported in Table 5.

Alternative approach to testing Hypothesis 2

We perform an alternative approach for Hypothesis 2 to directly test the relationship between pay-performance sensitivity and the propensity of combining financial and nonfinancial performance measures. Specifically, we estimate CEO bonus pay sensitivity to shareholder returns for each firm and term the resulting variable as PPS. To estimate PPS for each firm we use a mixed model with random coefficients as follows:

$\log \left(\right.$ Bonus $\left._{i t}\right)=\beta_{1 i} R E T_{i t}+\alpha_{i}+\varepsilon_{i t}$

The firm-specific coefficient $\beta_{1 i}$ represents $P P S$ for each firm. We investigate whether PPS is stronger for firms combining both performance measures in the following regression:

$P_{P S}=\beta_{1}$ Nonfinancial $_{i t}+\Sigma \beta_{k}$ Controls $_{k i t}+\alpha+\varepsilon_{i t}$

We expect a positive and significant coefficient $\beta_{l}$ in Hypothesis 2. We also use Nonfinancial Weight as an alternative to Nonfinancial. The results are presented in Table 8 . The first column in Table 8 shows a positive and significant relationship between PPS and Nonfinancial (coefficient of Nonfinancial is 0.15 , significant at the 1 percent level). The coefficient is also positive and significant when using Nonfinancial Weight as the independent variable (coefficient of Nonfinancial Weight is 0.34 , significant at the 1 percent level) as reported in the second column.

$<$ Insert Table 8 about here $>$ 


\section{Alternative measure of bonus pay}

We replicate the analysis in Table 5 using the percentage change in bonus from year $t-1$ to year $t$ as an alternative measure of the dependent variable, $\log$ (Bonus). We include only $R E T$ as the performance variable, following Jensen and Murphy (1990). The results (untabulated) are similar to those in Table 5.

\section{Control for CEO share ownership}

Nonfinancial performance measures and CEO ownership may be substitute incentive mechanisms (Schiehll and Bellavance, 2009). CEOs with high share ownership may have stronger incentives to increase their pay sensitivity to shareholder returns, not necessarily because they are evaluated by nonfinancial performance measures. Our results also show that higher CEO Power, which includes ownership power, is associated with less use of nonfinancial performance measures. Therefore, we control for CEO share ownership for Hypothesis 2. We rerun Equation (2) including the percentage of share ownership by CEOs as an additional control variable. We find (untabulated) that the coefficient of the CEO ownership variable is negative and significant (-0.04, significant at the 10 percent level), which is in line with the substitution effect of bonus pay and share ownership. The coefficient on Nonfinancial $\cdot R E T$ remains significant (1.10, significant at the 1 percent level).

In addition, we examine the use of nonfinancial performance measures across alternative levels of CEO ownership. This is in line with Ikäheimo, Kallunki, Moilanen, and Schiehll (2018) who try to disentangle whether employee pay represents incentive compensation or profit sharing through analyzing the variability of performance-based pay of three groups of employees (those with high, middle and low levels of task complexity). We divide our sample into those with low (less than 3 percent), medium (above 3 and less than 10 percent) and high (above 10 percent) levels of CEO ownership. For firms with the lowest CEO ownership, 63 
percent of the observations use a combination of financial and nonfinancial measures in bonus plans. For firms with medium share ownership, 89 percent of the observations use both types of performance measures. For firms with high CEO ownership, 50 percent of the observations employ nonfinancial performance measures. Therefore, there is no significant trend of higher or lower prevalence of using nonfinancial performance measures at different levels of CEO ownership. Overall, our main results are not likely to be driven by the substitution effect of CEO ownership.

\section{CONCLUSION}

This study examines the association between managerial power and the use of nonfinancial performance measures in CEO bonus plans, moderated by the monitoring role of compensation committees, and whether using nonfinancial performance measures is associated with increases in CEO bonus pay sensitivity to shareholder returns. Based on a sample of FTSE firms during the period 2007-2013, we find that firms with higher CEO power are less likely to use nonfinancial performance measures in CEO bonus compensation plans, consistent with the managerial power theory. However, we find that the influence of powerful CEOs over the board's decision of adopting nonfinancial measures is weakened by effective compensation committee monitoring. Specifically, the negative association between CEO power and the use of informative nonfinancial performance measures in bonus plans is less pronounced at higher levels of compensation committee monitoring. Our study contributes to the prior work on the choice of nonfinancial performance measures such as Ittner, Larcker and Rajan (1997) and Schiehll and Bellavance (2009).

We also document higher pay-performance sensitivity in firms that have integrated these nonfinancial performance measures in CEO bonus plans. Nonfinancial measures tend to discourage myopic CEO incentives associated with the traditional financial performance 
measures and improve the incentive power of compensation for maximizing shareholder returns. We also find that bonus pay-sensitivity to shareholder returns is stronger for firms placing more contractual weight on nonfinancial performance measures. Furthermore, we find that the improvement in pay-performance sensitivity from using nonfinancial performance measures is higher for firms with stronger compensation committee monitoring. These findings contribute to the literature on pay-performance sensitivity (e.g. Ozkan, 2011) by presenting the impact of the choice of performance measures on pay-performance sensitivity in the UK setting.

Our study provides the following practical implications. First, our results shed light on the importance of considering not only the role of the CEO but also the moderating effect of compensation committees in compensation-setting. Therefore, it highlights the value of strengthening the corporate governance structure to mitigate CEO's power in influencing the design of compensation contracts. Further regulation may be needed to enhance the committee's role in the governance structure. Second, we show that the incentive power of compensation for maximizing shareholder value is improved by including nonfinancial performance measures in CEO bonus compensation plans. The board of directors and its compensation committee should pay more attention to the combination of financial and nonfinancial performance measures when designing executive compensation contracts.

Our study has some limitations. Our measure of compensation is only captured by cash compensation, as data on total compensation is not fully available in the UK for our sample period. However, we believe that the impact of this limitation on our results is minimal given that the use of nonfinancial measures is predominant only in bonus compensation (Ibrahim and Lloyd, 2011). Furthermore, we rely on a sample of large firms in the UK and therefore results may not be generalizable in smaller firms in the UK or in firms in other countries. 


\section{REFERENCES}

Aguilera, R. V., Williams, C. A., Conley, J. M. \& Rupp, D. E. (2006). Corporate governance and social responsibility: a comparative analysis of the UK and the US. Corporate Governance: An International Review, 14, 147-158. DOI: 10.1111/j.1467-8683.2006.00495.x.

Anderson, R.C. \& Bizjak, J.M. (2003). An empirical examination of the role of the CEO and the compensation committee in structuring executive pay. Journal of Banking and Finance, 27(7): 1323-1348. DOI: 10.1016/S0378-4266(02)00259-5.

Andreas, J. M., Rapp, M. S., \& Wolff, M. (2012). Determinants of director compensation in two-tier systems: evidence from German panel data. Review of Managerial Science, 6(1), 33-79. DOI: 10.1007/s11846-010-0048-z.

Baker, G., Gibbons R., \& Murphy, K.J. (1994). Subjective performance measures in optimal incentive contracts. Quarterly Journal of Economics, 109 (4), 1124- 1156. DOI: $10.2307 / 2118358$

Banker, R. D. \& Datar, S. M. (1989). Sensitivity, precision, and linear aggregation of signals for performance evaluation. Journal of Accounting Research, 27(1), 21-39. DOI: $10.2307 / 2491205$

Banker, R. D., Potter, G., \& Srinivasan, D. (2000). An empirical investigation of an incentive plan that includes nonfinancial performance measures. The Accounting Review, 75(1), $65-92$.

Banker, R. D., Potter, G., \& Srinivasan, D. (2005). Association of nonfinancial performance measures with the financial performance of a lodging chain. Cornell Hotel and Restaurant Administration Quarterly, 46(4), 394-412. DOI: 10.1177/0010880405275597.

Beatty, R. P., \& Zajac, E. J. (1994). Managerial incentives, monitoring, and risk bearing: a 
study of executive compensation, ownership, and board structure in initial public offerings. Administrative Science Quarterly, 39(2), 313-335. DOI: 10.2307/2393238.

Bebchuk, L. A., \& Fried, J. M. (2004). Pay without performance: the unfulfilled promise of executive compensation. USA: Harvard University Press.

Bellavance, F., Landry, S., \& Schiehll, E. (2013). Procedural justice in managerial performance evaluation: Effects of subjectivity, relationship quality, and voice opportunity. The British Accounting Review, 45(3), 149-166. DOI: 10.1016/j.bar.2013.06.013.

Bender, R. \& Moir, L. (2006). Does 'Best Practice' in setting executive pay in the UK encourage 'Good' behaviour? Journal of Business Ethics, 67(1), 75-91. DOI: 10.1007/s10551-006-9006-8.

Buck, T., Bruce, A., Main, B. G. M., \& Udueni, H. (2003). Long term incentive plans, executive pay and UK company performance. The Journal of Management Studies, 40(7), 1709-1727. DOI: 10.1111/1467-6486.00397.

Bushman, R., Chen, Q., Engel, E., \& Smith, A. (2004). Financial accounting information, organizational complexity and corporate governance systems. Journal of Accounting and Economics, 37(2), 167-201. DOI: 10.1016/j.jacceco.2003.09.005.

Bushman, R.M., Indjejikian, R.J. \& Smith, A. (1996). CEO compensation: the role of individual performance evaluation. Journal of Accounting and Economics, 21(2), 161-193. DOI: $10.1016 / 0165-4101(95) 00416-5$.

Cadbury, A. (1992). Report of the committee on the financial aspects of corporate governance. UK: The Corporate Governance Committee.

Chen, C. X., Matsumura, E. M., Shin, J. Y., \& Wu, S. Y.-C. (2015). The effect of competition intensity and competition type on the use of customer satisfaction measures in executive 
annual bonus contracts. The Accounting Review, 90(1), 229-263.

Chin, M.K., Hambrick, D.C. \& Trevino, L.K. (2013). Political ideologies of CEOs: The influence of executives' values on corporate social responsibility. Administrative Science Quarterly, 58(2), 197-232. DOI: 10.1177/0001839213486984.

Combs, J. G., Ketchen, J., David J., Perryman, A. A. \& Donahue, M. S. (2007). The moderating effect of CEO power on the board composition-firm performance relationship. Journal of Management Studies, 44(8), 1299-1323. DOI: 10.1111/j.1467-6486.2007.00708.x.

Conyon, M.J. (1997). Corporate governance and executive compensation. International Journal of Industrial Organization, 15(4), 493-509. DOI: 10.1016/S0167-7187(96)01032-6.

Conyon, M.J. \& He, L. (2004). Compensation committees and CEO compensation incentives in U.S. entrepreneurial firms. Journal of Management Accounting Research, 16, 35-56.

Conyon, M.J., \& He, L. (2011). Executive compensation and corporate governance in China. Journal of Corporate Finance, 17(4), 1158-1175. DOI: 10.1016/j.jcorpfin.2011.04.006.

Conyon, M.J., \& He, L. (2012). CEO compensation and corporate governance in China. Corporate Governance: An International Review, 20(6), 575-592. DOI: 10.1111/j.1467-8683.2012.00935.x.

Conyon, M.J. \& Murphy, K.J. (2000). The prince and the pauper? CEO pay in the United States and the United Kingdom. The Economic Journal, 110 (November), F640-F671. DOI: 10.1111/1468-0297.00577.

Conyon, M.J. \& Peck, S.I. (1998). Board control, remuneration committees, and top management compensation. The Academy of Management Journal, 41(2), 146-157. DOI: $10.2307 / 257099$ 
Cordeiro, J., He, L., Conyon, M., \& Shaw, T. (2013). Informativeness of performance measures and Chinese executive compensation. Asia Pacific Journal of Management, 30(4), 1031-1058. DOI: 10.1007/s10490-013-9353-9.

Core, J.E., Holthausen, R.W., \& Larcker, D.F. (1999). Corporate governance, chief executive compensation, and firm performance. Journal of Financial Economics, 51, 371-406. DOI:10.1016/S0304-405X(98)00058-0.

Coughlan, A.T. \& Schmidt, R.M. (1985). Executive compensation, management turnover, and firm performance. Journal of Accounting \& Economics, 7, 43-66. DOI: $10.1016 / 0165-4101(85) 90027-8$.

Daily, C. M., Johnson, J. L., Ellstrand, A. E., \& Dalton, D. R. (1998). Compensation committee composition as a determinant of CEO compensation. Academy of Management Journal, 41(2), 209-220. DOI: 10.5465/257103.

Daily, C., \& Johnson, J. (1997). Sources of CEO power and firm financial performance: A longitudinal assessment. Journal of Management, 23(2), 97-117. DOI: 10.1016/S0149-2063(97)90039-8.

Davila, A., \& Venkatachalam, M. (2004). The relevance of non-financial performance measures for CEO compensation: evidence from the airline industry. Review of Accounting Studies, 9(4), 443-464. DOI: 10.1007/s11142-004-7792-8.

Epstein, M. J., \& Roy, M.-J. (2004). Improving the performance of corporate boards: Identifying and measuring the key drivers of success. Journal of General Management, 29(3), 1-23. DOI: 10.1177/030630700402900301.

Fahlenbrach, R., \& Stulz, R. M. (2011). Bank CEO incentives and the credit crisis. Journal of Financial Economics, 99(1), 11-26. DOI: 10.1016/j.jfineco.2010.08.010.

Feltham, G. A., \& Xie, J. (1994.) Performance measure congruity and diversity in multi-Task 
principal/agent relations. The Accounting Review, 69(3), 429-453.

Finkelstein, S. (1992). Power in top management teams: dimensions, measurement and validation. The Academy of Management Journal, 35 (3), 505-538. DOI: 10.2307/256485.

Finkelstein, S. \& D'aveni, R.A. (1994). CEO duality as a double-edged sword: How boards of directors balance entrenchment avoidance and unity of command. The Academy of Management Journal, 37(5), 1079-1108. DOI: 10.5465/256667.

Firth, M., Fung, P. M., \& Rui, O. M. (2007). How ownership and corporate governance influence chief executive pay in China's listed firms. Journal of Business Research, 60(7), 776-785. DOI: 10.1016/j.jbusres.2007.01.014.

Firth, M., Leung, T. Y., \& Rui, O. M. (2010). Justifying top management pay in a transitional economy. Journal of Empirical Finance, 17(5), 852-866. DOI: 10.1016/j.jempfin.2010.06.002.

Florackis, C. \& Ozkan, A. (2009). The impact of managerial entrenchment on agency costs: An empirical investigation using UK panel data. European Financial Management, 15(3), 497-528. DOI: 10.1111/j.1468-036X.2007.00418.x.

Garen, J. E. (1994). Executive compensation and principal-agent theory. Journal of Political Economy, 1175-1199.

Ghosh, D. \& Wu, A. (2012). The effect of positive and negative financial and nonfinancial performance measures on analysts' recommendations. Behavioral Research in Accounting, 24(2), 47-64. DOI: 10.2308/bria-10283.

Greenbury, R. (1995). Directors' remuneration. UK: The Confederation of British Industry.

Gregg, P., Machin, S., \& Szymanski, S. (1993). The disappearing relationship between directors' pay and corporate performance. British Journal of Industrial Relations, 31(1), 
1-9. DOI: 10.1111/j.1467-8543.1993.tb00377.x.

Hambrick, D.C. \& Fukutomi, G.D.S. (1991). The seasons of a CEO's tenure. Academy of Management Review, 16(4), 719-742. DOI: 10.2307/258978.

Han, S., Nanda, V. K., \& Silveri, S. (2016). CEO power and firm performance under pressure. Financial Management, 45(2), 369-400. DOI: 10.1111/fima.12127.

Hampel, R. (1998). Final report of the committee on corporate governance (January). Gee Publishing.

HassabElnaby, H. R., Mohamed, E. \& Said, A. A. (2010). Nonfinancial performance measures and earnings management, in Marc J. Epstein, John Y. Lee (ed.). Advances in Management Accounting, 18, 55-79.

Haynes, K.T. \& Hillman, A. (2010). The effect of board capital and CEO power on strategic change. Strategic Management Journal, 31(11), 1145-1163. DOI: https://doi.org/10.1002/smj.859.

Hill, C.W.L. \& Phan, P. (1991). CEO tenure as a determinant of CEO pay. The Academy of Management Journal, 34(3), 707-717. DOI: 10.2307/256413.

Hemmer, T. (1996). On the design and choice of "modern" management accounting measures. Journal of Management Accounting Research, 8, 87-116.

Holmstrom, B. (1979). Moral hazard and observability. The Bell journal of economics, 10(1), 74-91. DOI: $10.2307 / 3003320$.

Holmstrom, B., \& Milgrom, P. (1991). Multitask principal-agent analyses: incentive contracts, asset ownership, and job design. Journal of Law, Economics, \& Organization, 7, 24-52.

Hu, A., \& Kumar, P. (2004). Managerial entrenchment and payout policy. The Journal of Financial and Quantitative Analysis, 39(4), 759-790. 
Ibrahim, S., \& Lloyd, C. (2011). The association between non-financial performance measures in executive compensation contracts and earnings management. Journal of Accounting and Public Policy, 30(3), 256-274. DOI: 10.1016/j.jaccpubpol.2010.10.003.

Ikäheimo, S., Kallunki, J.-P., Moilanen, S. \& Schiehll, E. (2018). Do white-collar employee incentives improve firm profitability? Journal of Management Accounting Research, 30(3), 95-115. DOI: 10.2308/jmar-51902.

Ittner, C.D. \& Larcker, D.F. (1998). Are nonfinancial measures leading indicators of financial performance? an analysis of customer satisfaction. Journal of Accounting Research, 36, 1-35. DOI: $10.2307 / 2491304$.

Ittner, C.D., Larcker, D.F., \& Rajan, M.V. (1997). The choice of performance measures in annual bonus contracts. The Accounting Review, 72(2), 231-255.

Jensen, M. C., \& Meckling, W. H. (1976). Theory of the firm: managerial behavior, agency costs and ownership structure. Journal of Financial Economics, 3(4), 305-360. DOI: 10.1016/0304-405X(76)90026-X.

Jensen, M. C., \& Murphy, K. J. (1990). Performance pay and top-management incentives. Journal of Political Economy, 98(2), 225-264.

Kaplan, R. S. \& Norton, D. P. (1992). The balanced scorecard-measures that drive performance. Harvard Business Review, 70(1), 71-79.

Krause, R., Semadeni, M. \& Cannella, A. A. Jr. (2014). CEO duality: A review and research agenda. The Journal of Management, 40(1), 256-286. DOI: 10.1177/0149206313503013.

Laux, C. \& Laux, V. (2009). Board committees, CEO compensation, and earnings management. The Accounting Review, 84(3), 869-891.

Leone, A.J, Wu, J.S. \& Zimmerman, J.L. (2006). Asymmetric sensitivity of CEO cash 
compensation to stock returns. Journal of Accounting and Economics, 42 (1-2), 167-192. DOI: 10.1016/j.jacceco.2006.04.001.

Lo, K. and Wu, S. S. 2016. Private information in executive compensation: The information role vs. the monitoring role of the board. Corporate Governance: An International Review, 24(1), 5-23. DOI: 10.1111/corg.12122.

Mathew, S., Ibrahim, S. \& Archbold, S. (2018). Corporate governance and firm risk. Corporate Governance: The International Journal of Business in Society, 18(1), 52-67. DOI: 10.1108/CG-02-2017-0024.

McKnight, P. J., \& Tomkins, C. (1999). Top executive pay in the United Kingdom: A corporate governance dilemma. International Journal of the Economics of Business, 6(2), 223-243. DOI: 10.1080/13571519984241.

Newman, H.A. \& Mozes, H.A. (1999). Does the composition of the compensation committee influence CEO compensation Practices? Financial Management, 28(3), 41-53. DOI: $10.2307 / 3666182$

Opler, T. C., \& Titman, S. (1994). Financial distress and corporate performance. The Journal of Finance, 49(3), 1015-1040. DOI: 10.2307/2329214.

Ozkan, N. (2011). CEO compensation and firm performance: an empirical investigation of UK panel data. European Financial Management, 17(2), 260-285. DOI: 10.1111/j.1468-036X.2009.00511.x.

Petersen, M. A. (2009). Estimating standard errors in finance panel data sets: comparing approaches. Review of Financial Studies, 22(1), 435-480.

Pfeffer, J. 1981. Understanding the role of power in decision making. In: Power in Organizations, Marshfield, Mass.: Pitman, 404-423. 
Ryan Jr, H. E. \& Wiggins III, R. A. (2001). The influence of firm- and manager-specific characteristics on the structure of executive compensation. Journal of Corporate Finance, 7(2), 101-123. DOI: 10.1016/S0929-1199(00)00021-3.

Said, A. A., HassabElnaby, H. R., \& Wier, B. (2003). An empirical investigation of the performance consequences of nonfinancial measures. Journal of Management Accounting Research, 15(1), 193-223. DOI: 10.2308/jmar.2003.15.1.193.

Schaefer, S. (1998). The dependence of pay-performance sensitivity on the size of the firm. The Review of Economics and Statistics, 80(3), 436-443.

Schiehll, E. (2008). Private performance information in CEO incentive compensation. In Epstein, M.J. \& Manzoni, J-F (ed.) Performance Measurement and Management Control: Measuring and Rewarding Performance, Studies in Managerial and Financial Accounting $18,323-356$.

Schiehll, E. \& Bellavance, F. (2009). Boards of directors, CEO ownership, and the use of non-financial performance measures in the CEO bonus plan. Corporate Governance: An International Review, 17(1), 90-106. DOI: 10.1111/j.1467-8683.2008.00723.x.

Schiehll, E., Lewellyn, K. \& Muller-Kahle, M. I. (2018). Pilot, Pivot and Advisory Boards: The Role of Governance Configurations in Innovation Commitment. Organization Studies, 39(10), 1449-1472. DOI: 10.1177/0170840617717092.

Shaw, K. W. \& Zhang, M. H. (2010). Is CEO cash compensation punished for poor firm performance? The Accounting 1065-1093. DOI: 10.2308/accr.2010.85.3.1065.

Shen, W. \& Cannella, A. (2002). Power dynamics within top management and their impacts on CEO dismissal followed by inside succession. The Academy of Management Journal, 45(6), 1195-1206. DOI: DOI: 10.2307/3069434. 
Sliwka, D. (2002). On the use of nonfinancial performance measures in management compensation. Journal of Economics and Management Strategy, 11(3), 485-509. DOI: 10.1111/j.1430-9134.2002.00487.x.

Song, J. \& Windram, B. (2004). Benchmarking audit committee effectiveness in financial reporting. International Journal of Auditing, 8(3), 195-205. DOI: 10.1111/j.1099-1123.2004.00090.x.

Sun, J. \& Cahan, S. (2009). The effect of compensation committee quality on the association between CEO cash compensation and accounting performance. Corporate Governance: An International Review, 17(2), 193-207. DOI: 10.1111/j.1467-8683.2008.00726.x

UK Government (2013). The large and medium-sized companies and groups (accounts and reports) (amendment) regulations 2013. In UK Government (Ed.), 2013. No. 1981: 3-4. UK: The Stationery Office Limited.

UK Corporate Governance Code (2010). Financial Reporting Council, June, available at: https:/www.frc.org.uk/getattachment/31631a7a-bc5c-4e7b-bc3a-972b7f17d5e2/UK-CorpGov-Code-June-2010.pdf.

UK Corporate Governance Code (2016). Financial Reporting Council, April, available at: https://www.frc.org.uk/getattachment/ca7e94c4-b9a9-49e2-a824-ad76a322873c/UK-Corpo rate-Governance-Code-April-2016.pdf.

UK Corporate Governance Code (2018). Financial Reporting Council, July, available at: https://www.frc.org.uk/getattachment/88bd8c45-50ea-4841-95b0-d2f4f48069a2/2018-UKCorporate-Governance-Code-FINAL.PDF

van Essen, M., Otten, J. \& Carberry, E. J. (2015). Assessing managerial power theory: A meta-analytic approach to understanding the determinants of CEO compensation. Journal of Management, 41(1), 164-202. DOI: 10.1177/0149206311429378. 
Veprauskaite, E., \& Adams, M. (2013). Do powerful chief executives influence the financial performance of UK firms? The British Accounting Review, 45(3), 229-241. DOI: 10.1016/j.bar.2013.06.004.

Zhu, D.H. \& Chen, G.L. (2015). CEO narcissism and the impact of prior board experience on corporate strategy. Administrative Science Quarterly, 60(1), 31-65. DOI: $10.1177 / 0001839214554989$ 
TABLE 1

Sample Distribution by Use of Nonfinancial and Financial Performance Measures

Panel A: Sample Distribution by Year

\begin{tabular}{lrrrrr} 
& \multicolumn{2}{c}{$\begin{array}{c}\text { Financial Measures } \\
\text { Alone }\end{array}$} & \multicolumn{2}{c}{$\begin{array}{c}\text { Both Financial and } \\
\text { Nonfinancial Measures }\end{array}$} & Total \\
\hline Year & $\mathrm{N}$ & $\%$ & $\mathrm{~N}$ & $\%$ & $\mathrm{~N}$ \\
\hline 2007 & 60 & $41.38 \%$ & 85 & $58.62 \%$ & 145 \\
2008 & 66 & $39.76 \%$ & 100 & $60.24 \%$ & 166 \\
2009 & 55 & $32.35 \%$ & 115 & $67.65 \%$ & 170 \\
2010 & 66 & $37.08 \%$ & 112 & $62.92 \%$ & 178 \\
2011 & 56 & $36.84 \%$ & 96 & $63.16 \%$ & 152 \\
2012 & 56 & $36.36 \%$ & 98 & $63.64 \%$ & 154 \\
2013 & 45 & $34.09 \%$ & 87 & $65.91 \%$ & 132 \\
\hline Total & 404 & $36.83 \%$ & 693 & $63.17 \%$ & 1,097 \\
\hline
\end{tabular}

Panel B: Sample Distribution by Industry

$\begin{array}{cc}\text { Financial Measures } & \text { Both Financial and } \\ \text { Alone } & \text { Nonfinancial Measures }\end{array}$

Total

\begin{tabular}{lrrrrr}
\hline Industry & $\mathrm{N}$ & $\%$ & $\mathrm{~N}$ & $\%$ & $\mathrm{~N}$ \\
\hline Basic Materials & 15 & $18.52 \%$ & 66 & $81.48 \%$ & 81 \\
Consumer Goods & 71 & $51.08 \%$ & 68 & $48.92 \%$ & 139 \\
Consumer Services & 89 & $32.01 \%$ & 189 & $67.99 \%$ & 278 \\
Health Care & 4 & $8.89 \%$ & 41 & $91.11 \%$ & 45 \\
Industrials & 171 & $46.59 \%$ & 196 & $53.41 \%$ & 367 \\
Oil and Gas & 15 & $17.65 \%$ & 70 & $82.35 \%$ & 85 \\
Technology & 32 & $50.79 \%$ & 31 & $49.21 \%$ & 63 \\
Telecommunications & 7 & $17.95 \%$ & 32 & $82.05 \%$ & 39 \\
\hline Total & 404 & $36.83 \%$ & 693 & $63.17 \%$ & 1,097 \\
\hline
\end{tabular}


TABLE 2

Descriptive Statistics

Panel A:Full sample $(N=1,097)$

\begin{tabular}{lrrrr}
\hline Variable & Mean & Median & Q1 & Q3 \\
\hline CEO Bonus (£000) & 567.40 & 441.00 & 215.00 & 725.00 \\
Log(bonus) & 11.76 & 13.00 & 12.28 & 13.49 \\
Nonfinancial & 0.63 & 1.00 & 0.00 & 0.00 \\
Nonfinancial Weight (N=426) & 0.26 & 0.25 & 0.20 & 0.30 \\
RET & 0.17 & 0.12 & -0.14 & 0.38 \\
ROE & 0.17 & 0.16 & 0.08 & 0.25 \\
Total Assets (£Millions) & 9,329 & 1,760 & 753 & 4,325 \\
CEO Ownership Share Ratio & 5.01 & 0.69 & 0.24 & 1.55 \\
CEO Tenure & 6.72 & 5.00 & 3.00 & 9.00 \\
CEO Age & 52.27 & 52.00 & 48.00 & 56.00 \\
Duality & 0.02 & 0.00 & 0.00 & 0.00 \\
Compensation Committee Independence & 0.90 & 1.00 & 0.80 & 1.00 \\
Compensation Committee Size & 4.15 & 4.00 & 3.00 & 5.00 \\
Compensation Committee Chair Independence & 0.96 & 1.00 & 1.00 & 1.00 \\
Board Size & 9.20 & 9.00 & 7.00 & 10.00 \\
Board Independence & 0.61 & 0.60 & 0.50 & 0.70 \\
Firm Size & 21.45 & 21.29 & 20.44 & 22.19 \\
Firm Age & 67.33 & 42.00 & 20.00 & 104.00 \\
Leverage & 0.30 & 0.28 & 0.20 & 0.38 \\
Market-to-book & 4.27 & 2.53 & 1.42 & 4.27 \\
Financial Crisis & 0.28 & 0.00 & 0.00 & 1.00 \\
Herfindahl Index & 0.03 & 0.01 & 0.00 & 0.03 \\
\hline & & & & \\
\hline Din & & &
\end{tabular}

Panel B: Comparison of firms using financial measures alone and those combining financial and nonfinancial measures

\begin{tabular}{|c|c|c|c|c|c|c|}
\hline \multirow[b]{2}{*}{ Variable } & \multicolumn{2}{|c|}{$\begin{array}{c}\text { Financial Measures } \\
\text { Alone } \\
(\mathrm{N}=404)\end{array}$} & \multicolumn{2}{|c|}{$\begin{array}{l}\text { Both Financial and } \\
\text { Nonfinancial Measures } \\
(\mathrm{N}=693)\end{array}$} & \multirow{2}{*}{\multicolumn{2}{|c|}{$\begin{array}{c}\text { t-statistic/ } \\
\text { Chi-square } \\
\text { statistic }\end{array}$}} \\
\hline & Mean & Median & Mean & Median & & \\
\hline RET & 0.17 & 0.13 & 0.16 & 0.10 & 0.32 & \\
\hline$R O E$ & 0.25 & 0.20 & 0.12 & 0.13 & 3.18 & $* * *$ \\
\hline CEO Power & 1.69 & 2.00 & 1.52 & 2.00 & 16.85 & $* * *$ \\
\hline Monitoring & 2.23 & 2.00 & 2.32 & 2.00 & 8.35 & $* *$ \\
\hline
\end{tabular}

Panel A presents descriptive statistics for all variables in the full sample. CEO Bonus = annual bonus of CEO; $\log ($ Bonus $)=\log$ transformation of the annual CEO bonus $(+1)$; Nonfinancial $=1$ if a firm includes nonfinancial performance measures in its CEO's annual bonus compensation plans, 0 otherwise; Nonfinancial Weight $=$ the relative weight placed on nonfinancial performance measures in CEO bonus compensation, when disclosed; $R E T=$ Annualized stock return; $R O E=$ Return on equity measured as net income divided by total shareholders' equity; Total Assets = Total assets of firm at end of year; CEO Ownership Share Ratio = total shares owned by CEO divided by total shares owned by other board members; $C E O$ Tenure $=$ number of years CEO has been in position; CEO Age = age of CEO; Duality $=1$ if the CEO also holds title of Chairman of the board, 0 otherwise; Compensation Committee Independence = percentage of committee members classified as 
independent; Compensation Committee Size = number of members of committee; Compensation Committee Chair Independence $=1$ if committee chair is independent, 0 otherwise; Board Size = number of members of board of directors; Board Independence = percentage of board members classified as independent; Firm Size = $\log$ transformation of the book value of total assets in year; Firm Age = The number of years since the firm's founding year; Leverage $=$ total debt divided by total assets; Market-to-book $=$ market value of shares divided by total assets; Financial Crisis $=1$ if the observation is during the period 2007-2008, 0 otherwise; Herfindahl Index = sum of squared market share of the firm, where a firm's market share is its percentage share of sales revenues within its industry; Panel B presents mean and median for the main test variables in firms that use financial measures in CEO bonus plans alone and those that combine financial and nonfinancial measures. $C E O$ Power $=$ Index representing power of CEO; Monitoring $=$ Index representing effectiveness of monitoring of the board through the compensation committee; ** and *** represent significance at $5 \%$ and $1 \%$, respectively, using a t-test of difference in means for continuous variables and Chi-square test for categorical variables. 
TABLE 3

Correlation Matrix

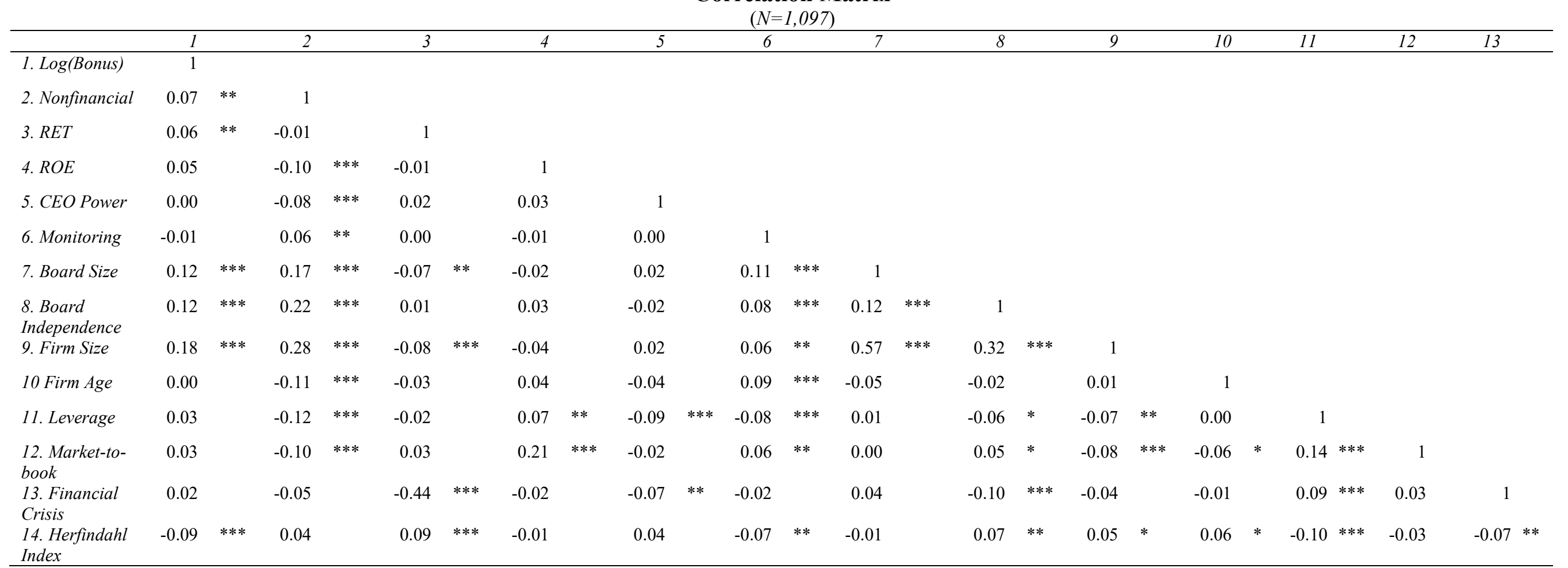

All variables are defined in Table $2{ }^{*},{ }^{* *}$, and $* * *$ represents significance at $10 \%, 5 \%$ and $1 \%$, respectively. 


\section{TABLE 4}

\section{Effect of Managerial Power on the Propensity of Using Nonfinancial Measures}

The table presents coefficients (p-values) from the following regression:

Nonfinancial $_{i t}=\beta_{1}$ CEO Power $_{i t-1}+\beta_{2}$ CEO Power $_{i t-1} \cdot$ Monitoring $_{i t-1}+\beta_{3}$ Monitoring $_{i t-1}+\sum \beta_{k}$ Controls $_{k i, t-1}$ $+\alpha+\varepsilon_{i t}, \quad$ (1) where Nonfinancial $_{i t}$ is replaced with Nonfinancial Weight ${ }_{i t}$ in the second column.

\begin{tabular}{|c|c|c|c|c|}
\hline \multirow{2}{*}{$\begin{array}{l}\text { Dependent Variable }= \\
\text { Independent Variable }\end{array}$} & \multicolumn{2}{|c|}{ Nonfinancial } & \multicolumn{2}{|c|}{ Nonfinancial Weight } \\
\hline & & & & \\
\hline \multirow[t]{2}{*}{ CEO Power } & -1.09 & $* * *$ & -0.04 & $* *$ \\
\hline & $(0.00)$ & & $(0.02)$ & \\
\hline \multirow[t]{2}{*}{ CEO Power $\cdot$ Monitoring } & 0.38 & $* * *$ & 0.01 & $*$ \\
\hline & $(0.01)$ & & $(0.07)$ & \\
\hline \multirow[t]{2}{*}{ Monitoring } & -0.33 & & 0.01 & \\
\hline & $(0.26)$ & & $(0.71)$ & \\
\hline \multirow[t]{2}{*}{$R E T$} & -0.06 & & -0.02 & \\
\hline & $(0.65)$ & & $(0.14)$ & \\
\hline \multirow[t]{2}{*}{$R O E$} & -0.15 & & -0.01 & \\
\hline & $(0.19)$ & & $(0.15)$ & \\
\hline \multirow[t]{2}{*}{ Firm Size } & 0.47 & $* * *$ & 0.03 & $* * *$ \\
\hline & $(0.00)$ & & $(0.00)$ & \\
\hline \multirow[t]{2}{*}{ Firm Age } & 0.00 & $*$ & 0.00 & $* * *$ \\
\hline & $(0.08)$ & & $(0.00)$ & \\
\hline \multirow[t]{2}{*}{ Leverage } & -1.46 & & -0.13 & $* * *$ \\
\hline & $(0.14)$ & & $(0.00)$ & \\
\hline \multirow[t]{2}{*}{ Market-to-book } & -0.02 & & 0.00 & \\
\hline & $(0.17)$ & & $(0.87)$ & \\
\hline \multirow[t]{2}{*}{ Financial Crisis } & -0.04 & & -0.01 & \\
\hline & $(0.80)$ & & $(0.38)$ & \\
\hline \multirow[t]{2}{*}{ Herfindahl Index } & 0.9 & & 0.19 & $* * *$ \\
\hline & $(0.41)$ & & $(0.01)$ & \\
\hline Industry & Yes & & Yes & \\
\hline Year & Yes & & Yes & \\
\hline \multirow[t]{2}{*}{ Constant } & -7.41 & $* * *$ & -0.49 & $* * *$ \\
\hline & $(0.01)$ & & $(0.00)$ & \\
\hline Observations & 816 & & 635 & \\
\hline$R^{2}$ & 0.13 & & 0.1 & \\
\hline
\end{tabular}

Industry $=$ Industry indicator based on 8 FTSE Industry Classification Benchmark (ICB) industries; Year = Fiscal year indicator based on the sample period 2007-2013; All other variables are defined in Table 2; *,**, and $* * *$ represents significance at $10 \%, 5 \%$ and $1 \%$, respectively. 
TABLE 5

Effect of Nonfinancial Performance Measures on CEO Bonus Pay Sensitivity to Shareholder Returns

The table presents coefficients (p-values) from the following regression:

$\log \left(\right.$ Bonus $\left._{i t}\right)=\beta_{1} R E T_{i t}+\beta_{2}$ Nonfinancial $_{i t} \cdot R E T_{i t}+\beta_{3} R O E_{i t}+\beta_{4}$ Nonfinancial $_{i t} \cdot R O E_{i t}+\beta_{5}$ Nonfinancial $_{i t}$ $+\sum \beta_{k}$ Controls $_{k i t}+\alpha+\varepsilon_{i t,}$ (2)

where Nonfinancial is $_{\text {it }}$ replaced with Nonfinancial Weight ${ }_{i t}$ as an alternative independent variable in the second column.

\begin{tabular}{|c|c|c|}
\hline Independent Variable & Nonfinancial & Nonfinancial Weight \\
\hline \multirow[t]{2}{*}{$R E T$} & 0.24 & 0.32 \\
\hline & $(0.59)$ & $(0.46)$ \\
\hline \multirow[t]{2}{*}{ Nonfinancial $\cdot R E T$} & $1.13 * *$ & 2.72 \\
\hline & $(0.03)$ & $(0.16)$ \\
\hline \multirow[t]{2}{*}{$R O E$} & -0.11 & -0.15 \\
\hline & $(0.71)$ & $(0.60)$ \\
\hline \multirow[t]{2}{*}{ Nonfinancial $\cdot R O E$} & $0.73 *$ & 1.35 \\
\hline & $(0.06)$ & $(0.25)$ \\
\hline \multirow[t]{2}{*}{ Nonfinancial } & -0.07 & -1.20 \\
\hline & $(0.80)$ & $(0.26)$ \\
\hline \multirow[t]{2}{*}{ Board Size } & 0.05 & 0.07 \\
\hline & $(0.43)$ & $(0.31)$ \\
\hline \multirow[t]{2}{*}{ Board Independence } & $2.70 * * *$ & $2.99 * *$ \\
\hline & $(0.01)$ & $(0.02)$ \\
\hline \multirow[t]{2}{*}{ Firm Size } & $0.41 * * *$ & $0.51 * * *$ \\
\hline & $(0.00)$ & $(0.00)$ \\
\hline \multirow[t]{2}{*}{ Firm Age } & 0.00 & 0.00 \\
\hline & $(0.63)$ & $(0.83)$ \\
\hline \multirow[t]{2}{*}{ Leverage } & 0.73 & 1.44 \\
\hline & $(0.37)$ & $(0.14)$ \\
\hline \multirow[t]{2}{*}{ Market-to-book } & 0.01 & 0.01 \\
\hline & $(0.34)$ & $(0.47)$ \\
\hline \multirow[t]{2}{*}{ Financial Crisis } & $0.63 * *$ & 0.47 \\
\hline & $(0.03)$ & $(0.18)$ \\
\hline \multirow[t]{2}{*}{ Herfindahl Index } & $-5.15 * * *$ & $-3.91 * *$ \\
\hline & $(0.00)$ & $(0.02)$ \\
\hline Industry & Yes & Yes \\
\hline Year & Yes & Yes \\
\hline \multirow[t]{2}{*}{ Constant } & 0.49 & -2.00 \\
\hline & $(0.80)$ & $(0.39)$ \\
\hline Observations & 1,097 & 830 \\
\hline$R^{2}$ & 0.07 & 0.07 \\
\hline
\end{tabular}




\section{TABLE 6}

\section{Effect of Nonfinancial Measures on CEO Bonus Pay Sensitivity to Shareholder Returns - High versus Low Committee Independence}

The table presents coefficients (p-values) from the following regression:

$\log \left(\right.$ Bonus $\left._{i t}\right)=\beta_{1} R E T_{i t}+\beta_{2}$ Nonfinancial $_{i t} \cdot$ RET $_{i t}+\beta_{3} R O E_{i t}+\beta_{4}$ Nonfinancial $_{i t} \cdot$ ROE $_{i t}+\beta_{5}$ Nonfinancial $_{i t}$ $+\sum \beta_{k}$ Controls $_{k i t}+\alpha+\varepsilon_{i t}$

\begin{tabular}{|c|c|c|c|}
\hline Independent Variable & $\begin{array}{c}\text { Low } \\
\text { Committee } \\
\text { Independence }\end{array}$ & \multicolumn{2}{|c|}{$\begin{array}{c}\text { Committee } \\
\text { Independence }\end{array}$} \\
\hline \multirow[t]{2}{*}{$R E T$} & 0.97 & -0.04 & \\
\hline & $(0.25)$ & $(0.94)$ & \\
\hline \multirow[t]{2}{*}{ Nonfinancial $\cdot R E T$} & 0.45 & 1.39 & $* *$ \\
\hline & $(0.64)$ & $(0.02)$ & \\
\hline \multirow[t]{2}{*}{$R O E$} & -0.11 & -0.29 & \\
\hline & $(0.83)$ & $(0.42)$ & \\
\hline \multirow[t]{2}{*}{ Nonfinancial $\cdot R O E$} & 0.92 & 0.88 & $*$ \\
\hline & $(0.41)$ & $(0.05)$ & \\
\hline \multirow[t]{2}{*}{ Nonfinancial } & -0.14 & -0.02 & \\
\hline & $(0.79)$ & $(0.95)$ & \\
\hline \multirow[t]{2}{*}{ Board Size } & 0.11 & 0.01 & \\
\hline & $(0.22)$ & $(0.87)$ & \\
\hline \multirow[t]{2}{*}{ Board Independence } & 2.55 & 2.89 & $* *$ \\
\hline & $(0.16)$ & $(0.04)$ & \\
\hline \multirow[t]{2}{*}{ Firm Size } & $0.36 *$ & 0.43 & $* * *$ \\
\hline & $(0.05)$ & $(0.00)$ & \\
\hline \multirow[t]{2}{*}{ Firm Age } & 0.00 & 0.00 & \\
\hline & $(0.22)$ & $(0.11)$ & \\
\hline \multirow[t]{2}{*}{ Leverage } & 0.08 & 1.15 & \\
\hline & $(0.95)$ & $(0.26)$ & \\
\hline \multirow[t]{2}{*}{ Market-to-Book } & 0.06 & 0.01 & \\
\hline & $(0.30)$ & $(0.52)$ & \\
\hline \multirow[t]{2}{*}{ Financial Crisis } & 0.30 & 0.81 & $* *$ \\
\hline & $(0.55)$ & $(0.03)$ & \\
\hline \multirow[t]{2}{*}{ Herfindahl Index } & $-8.50 * *$ & -3.42 & $* *$ \\
\hline & $(0.00)$ & $(0.04)$ & \\
\hline Industry & Yes & Yes & \\
\hline Year & Yes & Yes & \\
\hline \multirow[t]{2}{*}{ Constant } & 1.56 & -0.18 & \\
\hline & $(0.65)$ & $(0.94)$ & \\
\hline Observations & 395 & 702 & \\
\hline$R^{2}$ & 0.09 & 0.08 & \\
\hline
\end{tabular}

All variables are defined in Table $2 ; *, * *$, and *** represents significance at $10 \%, 5 \%$ and $1 \%$, respectively; Low committee independence is the group of firms where at least one member of the compensation committee is not independent; High committee independence is the group of firms where all members of the compensation committee are independent (median compensation committee independence $=100 \%$ ). 
TABLE 7

Effect of Nonfinancial Measures on CEO Bonus Pay Sensitivity to Shareholder Returns - Two-stage regressions

The table presents coefficients (p-values) from the following regression:

$\log \left(\right.$ Bonus $\left._{i t}\right)=\beta_{1} R T_{i t}+\beta_{2}$ Nonfinancial $_{i t}$ RET $_{i t}+\beta_{3}$ ROE $_{i t}+\beta_{4}$ Nonfinancial $_{i t} \cdot$ ROE $_{i t}+\beta_{5}$ Nonfinancial $_{i t}$ $+\sum \beta_{k}$ Controls $_{k i t}+\alpha+\varepsilon_{i t,}$ (2)

where Nonfinancial it $_{\text {is }}$ replaced with Nonfinancial Weight ${ }_{i t}$ in the second column.

\begin{tabular}{|c|c|c|}
\hline Independent Variable & Nonfinancial & Nonfinancial Weight \\
\hline \multirow[t]{2}{*}{$R E T$} & $-2.81 * * *$ & $-1.92 * *$ \\
\hline & $(0.01)$ & $(0.02)$ \\
\hline \multirow[t]{2}{*}{ Nonfinancial $\cdot R E T$} & $5.78 * * *$ & $19.84 * * *$ \\
\hline & $(0.00)$ & $(0.00)$ \\
\hline \multirow[t]{2}{*}{$R O E$} & -1.02 & -0.43 \\
\hline & $(0.14)$ & $(0.54)$ \\
\hline \multirow[t]{2}{*}{ Nonfinancial $\cdot R O E$} & $2.04 *$ & 3.64 \\
\hline & $(0.07)$ & $(0.39)$ \\
\hline \multirow[t]{2}{*}{ Nonfinancial } & $-5.55 * * *$ & $-14.98 * *$ \\
\hline & $(0.00)$ & $(0.01)$ \\
\hline \multirow[t]{2}{*}{ Board Size } & 0.02 & 0.06 \\
\hline & $(0.77)$ & $(0.48)$ \\
\hline \multirow[t]{2}{*}{ Board Independence } & $3.35 * * *$ & $3.63 * *$ \\
\hline & $(0.01)$ & $(0.02)$ \\
\hline \multirow[t]{2}{*}{ Firm Size } & $0.81 * * *$ & $0.88 * * *$ \\
\hline & $(0.00)$ & $(0.00)$ \\
\hline \multirow[t]{2}{*}{ Firm Age } & 0.00 & 0.00 \\
\hline & $(0.18)$ & $(0.14)$ \\
\hline \multirow[t]{2}{*}{ Leverage } & 0.07 & 1.16 \\
\hline & $(0.95)$ & $(0.41)$ \\
\hline \multirow[t]{2}{*}{ Market-to-book } & 0.01 & 0.02 \\
\hline & $(0.76)$ & $(0.46)$ \\
\hline \multirow[t]{2}{*}{ Financial Crisis } & 0.22 & 0.01 \\
\hline & $(0.60)$ & $(0.98)$ \\
\hline \multirow[t]{2}{*}{ Herfindahl Index } & $-5.13 * * *$ & $-4.15 * *$ \\
\hline & $(0.00)$ & $(0.05)$ \\
\hline Industry & Yes & Yes \\
\hline Year & Yes & Yes \\
\hline \multirow[t]{2}{*}{ Constant } & -4.11 & $-7.87 *$ \\
\hline & $(0.17)$ & $(0.08)$ \\
\hline Observations & 816 & 627 \\
\hline$R^{2}$ & 0.08 & 0.08 \\
\hline
\end{tabular}




\section{TABLE 8}

\section{Effect of Nonfinancial Measures on CEO Bonus Pay Sensitivity to Shareholder Returns - Alternative Methodology}

The table presents coefficients (p-values) from the following regression:

$P P S_{i t}=\beta_{1}$ Nonfinancial $_{i t}+\Sigma \beta_{k}$ Controls $_{k i t}+\alpha+\varepsilon_{i t}$, (4)

where $P P S_{i t}$ is the firm-specific variable estimated from the following random effect model:

$\log \left(\right.$ Bonus $\left._{i t}\right)=\beta_{1 i} R E T_{i t}+\alpha_{i}+\varepsilon_{i t,} \quad$ (3)

We replace Nonfinancial ${ }_{i t}$ with Nonfinancial Weight ${ }_{i t}$ in the second column

\begin{tabular}{|c|c|c|c|}
\hline \multirow{2}{*}{$\begin{array}{l}\text { Dependent Variable }= \\
\text { Independent Variable }\end{array}$} & \multicolumn{3}{|c|}{$P P S(R E T)$} \\
\hline & Nonfinancial & Nonfinanci & al Weight \\
\hline \multirow[t]{2}{*}{ Nonfinancial } & $0.15 * * *$ & 0.34 & $* * *$ \\
\hline & $(0.00)$ & $(0.00)$ & \\
\hline \multirow[t]{2}{*}{ Board Size } & 0.15 & 0.08 & \\
\hline & $(0.14)$ & $(0.50)$ & \\
\hline \multirow[t]{2}{*}{ Board Independence } & $0.02 * * *$ & 0.02 & $* * *$ \\
\hline & $(0.00)$ & $(0.00)$ & \\
\hline \multirow[t]{2}{*}{ Firm Size } & 0.01 & 0.02 & \\
\hline & $(0.33)$ & $(0.12)$ & \\
\hline \multirow[t]{2}{*}{ Firm Age } & $0.00 *$ & 0.00 & $* * *$ \\
\hline & $(0.06)$ & $(0.00)$ & \\
\hline \multirow[t]{2}{*}{ Leverage } & -0.12 & -0.13 & \\
\hline & $(0.19)$ & $(0.26)$ & \\
\hline \multirow[t]{2}{*}{ Market-to-book } & 0.00 & 0.00 & \\
\hline & $(0.26)$ & $(0.16)$ & \\
\hline \multirow[t]{2}{*}{ Financial Crisis } & -0.05 & -0.04 & \\
\hline & $(0.30)$ & $(0.56)$ & \\
\hline \multirow[t]{2}{*}{ Herfindahl Index } & 0.09 & 0.06 & \\
\hline & $(0.63)$ & $(0.79)$ & \\
\hline Industry & Yes & Yes & \\
\hline Year & Yes & Yes & \\
\hline \multirow[t]{2}{*}{ Constant } & $0.96 * * *$ & 0.81 & $* * *$ \\
\hline & $(0.00)$ & $(0.01)$ & \\
\hline Observations & 1,097 & 830 & \\
\hline$R^{2}$ & 0.07 & 0.07 & \\
\hline
\end{tabular}

PPS represents pay-performance sensitivity for each observation which is the coefficient $\left(\beta_{l i}\right)$ from regression (3) estimated with the random effect model; All variables are defined in Table $2 ; *$, **, and *** represents significance at $10 \%, 5 \%$ and $1 \%$, respectively. 


\section{ENDNOTES:}

1 These categories are similar to those used in Ittner, Larcker and Rajan (1997).

${ }^{2}$ NRG Metrics is a corporate governance and ownership database created by a team of market professionals and academic researchers in the field of corporate governance.

${ }^{3}$ Sun and Cahan (2009) argue that compensation committee quality can be either higher or lower when the size of the compensation committee is smaller. On the one hand, smaller boards can be more influenced by CEOs; but on the other hand, smaller boards may be more effective due to less free riding problems. As a robustness test, we measure board monitoring excluding compensation committee size as an alternative proxy for Monitoring and find similar results.

${ }^{4}$ For ease of presentation we exclude the firm subscript $i$ and time subscript $t$ from the tables of results and discussion within the document.

${ }^{5}$ When using Nonfinancial Weight as the dependent variable, which is a continuous variable, we use ordinary least square regressions with clustered standard errors.

${ }^{6}$ If market share data is not available in a particular industry/year combination, we set the Herfindahl Index to zero so as not to lose observations. Our results do not change qualitatively when we exclude observations without the Herfindahl index.

${ }^{7}$ Leone, Wu and Zimmerman (2006) and Shaw and Zhang (2010) use return on assets (ROA) instead of ROE as the accounting performance measure.

${ }^{8}$ They proxy CEO power with several variables - e.g. number of board members appointed after CEO appointment and duality - and find a negative relationship with Nonfinancial Weight.

${ }_{9}$ We also use an alternative grouping based on the board monitoring index: the group with low board monitoring includes observations where the index for Monitoring is less than 2 and the group with high board monitoring includes observations where Monitoring is greater than or equal to 2. In untabulated results, we find that the positive coefficient on Nonfinancial-RET only holds in the group with high board monitoring. 